\title{
PERCY SHELLEY’S ‘I VISIT THEE BUT THOU ART SADLY CHANGED’
}

The first line of Percy Bysshe Shelley's 'I visit thee but thou art sadly changed' contains an allusion to Byron that allows for a reconsideration of this lyric blank verse fragment. ${ }^{1}$ Neville Rogers first published the fragment in 1975; it was then included in The Poems of Shelley edited by Geoffrey Matthews and Kelvin Everest, and Michael J. Neth has recently commented on it in The Complete Poetry of Percy Bysshe Shelley. ${ }^{2}$ There has been some disagreement over which lines in Bodleian MS. Shelley adds. e. 10 comprise 'I visit thee'. I take the text to run from the top of p. 126 to the bottom of p. 127, and to consist of twelve lines-from 'I visit thee but thou art sadly changed' to 'which [?heap] forth sorrow' —of which ten lines are in fairly regular iambic pentameter and two lines are unfinished (ll. 10, 12). I do not think the lines on p. 128a and p. 129a relate to 'I visit thee' for four reasons: their metrical irregularity, the steadier hand of these lines, the presence of a rhyme on p. 129a, and because I agree with Neth that these later pages are early plans and drafts for stanzas for the 1817 poem Laon and Cythna $(L \& C) .{ }^{3}$

There is a range of possible dates for the composition of 'I visit thee'; those proposed range from April to late July 1817. Some more precise dates have been suggested, including late July 1817 , based on calculations from the $380^{\text {th }}$ stanza of $L \& C$, which Shelley claimed to have reached in a letter to Leigh Hunt of 3 August (this is the only surviving mention of composing $L \& C$ in correspondence), and 26 April-9 May 1817, due to his proximity to Bishopsgate which has been thought to be the 'former home' addressed in the lyric. ${ }^{4}$ Although these precise dates are plausible, I think it judicious to prefer a broad date range (April-July 1817) because placing 'I visit thee' exactly among the difficult composition calendar of $L \& C$ is impossible, and because I do not think the 'home' of line 2 need refer exclusively to Bishopsgate. ${ }^{5}$

The lyric is roughly written in pencil over two notebook pages and the first page also features at its centre a pencil and ink drawing of a mountain scene with a boat on a lake. The first two lines of 'I visit thee' are:

I visit thee but thou art sadly changed

\footnotetext{
${ }^{1}$ Bodleian MS. Shelley adds. e. 10, pp. 126-27. Reproduced in The Bodleian Shelley Manuscripts Volume XVII, ed. S. Jones (New York: Garland, 1994), 134-136.

2 The Complete Poetical Works of Percy Bysshe Shelley, ed. N. Rogers (Oxford: Clarendon Press, 1972-1975), II, 371; The Poems of Shelley, ed. K. Everest and G. M. Matthews, et al. (London: Longman, 1989-2013), I, 571-72; The Complete Poetry of Percy Bysshe Shelley, ed. D. H. Reiman, N. Fraistat, et al. (Baltimore: Johns Hopkins University Press, 2003-2012), III, 930-31.

3 The Complete Poetry of Percy Bysshe Shelley, III, 931.

${ }^{4}$ For a discussion of the dating see, The Poems of Shelley, I, 571; The Complete Poetry of Percy Bysshe Shelley, III, 930-31; The Bodleian Shelley Manuscripts Volume XVII, xiii-xiv.

5 The difficult composition order of $L \& C$ is outlined in The Complete Poetry of Percy Bysshe Shelley, III, 555-561.
} 
Thy former home is now made desolate 6

Shelley's lyric opens with an hitherto unnoticed allusion to Byron's 1813 poem The Bride of Abydos (The Bride). Zuleika's speech in Canto I section 13 begins with the following lines, from which Shelley took the words 'thou art sadly changed' verbatim:

'Think not thou art what thou appearest!

My Selim, thou art sadly changed'7

This is not the first time Shelley had borrowed a phrase from Byron-St. Irvyne (1810) contains a whole line from Poems: Original and Translated (1808)-but the presence of Byron in 'I visit thee' reveals a particularly interesting interaction between the two poets. ${ }^{8}$ There are two elements of the position of this lyric in the notebook that elucidate Shelley's allusion: first, the relationship between $L \& C$ and Byron's poetry from 1812-1816, and secondly the specific incest theme that the two poets shared.

$L \& C$ has a close relationship to Byron's poetry, and has been viewed by some as Shelley's attempt to bring a positive revolutionary character to the protagonists of Byron's 'Turkish Tales' and Childe Harold's Pilgrimage (18121818). ${ }^{9}$ In a draft of the first stanzas of $L \& C$ in another notebook, Shelley writes, 'Is this an imitation of Ld. Byron's poem?'.10 The remark shows Shelley's anxiety over formally imitating the Spenserian stanza of Childe Harold, while the poem itself realises his desire to change the morose Harold for the 'unbounded and sustained enthusiasm' of $L \& C .11$ When Shelley resumed $L \& C$ after writing 'I visit thee' he was again thinking about Byron, and admitted in a note (some 50 pages after the lyric) to an 'involuntary imitation' of a plot device from The Corsair (1814). ${ }^{12}$ The presence of the phrase 'thou art sadly changed' in a lyric composed during Shelley's attempt to write a long poem in dialogue with Byron reveals the younger poet's sensitivity towards Byron's poetry, and is part of what Jack Donovan has called Shelley's 'anxiously tentative relation' with a poet who he wished would become 'a fountain from which the thoughts of other men shall draw strength and beauty'.13

The lines borrowed from The Bride in 'I visit thee' have a local relevance to $L \& C$. The Bride and $L \& C$ share incest plots, and Shelley had already included an

\footnotetext{
${ }^{6}$ MS. Shelley adds. e. 10, p. 126.

${ }^{7}$ Lord Byron, The Complete Poetical Works, ed. J. J. McGann (Oxford: Clarendon press, 19801993), III, 120.

${ }^{8}$ A point first established in The Prose work of Percy Bysshe Shelley, ed. Richard H. Shepherd (London: Chatto and Windus, 1888) I, 132.

${ }^{9}$ See, for example, Charles E. Robinson, Shelley and Byron: the Snake and Eagle Wreathed in Fight (Baltimore: Johns Hopkins University Press, 1976), 14-40, 60-80.

${ }^{10}$ Bodleian MS. Shelley adds. e. 19, p. 3. Reproduced in The Bodleian Shelley Manuscripts Volume

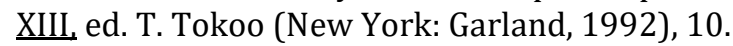

${ }^{11}$ The Letters of Percy Bysshe Shelley, ed. F. L. Jones (Oxford: Clarendon Press, 1964), I, 577.

12 MS. Shelley adds. e. 10, p. 182. Reproduced in The Bodleian Shelley Manuscripts Volume XVII, 198. See, B. W. Griffith, "'The Revolt of Islam" and Byron's “The Corsair"' N\&Q 201 (1956), 265. 13 The Poems of Shelley, II, 21; The Letters of Percy Bysshe Shelley, I, 507.
} 
allusion to Byron's tale of incest Parisina (1816) in his long poem. ${ }^{14}$ The words of Zulieka borrowed by Shelley relate to the incest of The Bride, and come as Selim and Zulieka realise that familial ties are not changeable; as Zulieka's father Giaffir tells her earlier in the poem, 'the line of Carasman / Unchanged - unchangeable hath stood'. ${ }^{15}$ Shelley had The Bride in mind while constructing his incest plot in $L \& C$, and lines from this work then found their way into 'I visit thee'. There is a further connection between The Bride, 'I visit thee' and $L \& C$, in a stanza drafted shortly after this lyric in MS. Shelley adds. e. 10. The climax of Cythna's speech at the close of Canto IX-'Lo! what a change is come / Since I first spake - but time shall be forgiven, / Tho' it change all but thee!'-hints at Zulieka's statement in The Bride and ll. 8-9 of 'I visit thee' ('I am changed, and many things are changed / The Earth the Forests and the Sky remain'). ${ }^{16}$ This speech, drafted eight pages later in the notebook, parallels the succession of natural and climatic nouns in 'I visit thee', with the 'waters', 'Earth', 'Heaven', 'sea', 'air', 'clouds' and 'wind' of Shelley's stanza matching the 'winds', 'moon', 'stars', 'sun', 'Earth', Forest', 'Sky' of the fragment. ${ }^{17}$ The interplay between these three works shows that 'I visit thee' is marked by its coincidental composition with $L \& C$, at a time when Shelley was reading Byron's poetry and appears to have been reflecting on a personal change.

To move closer to what this change or loss might be requires the exploration of a further Byronic connection, one that relates the allusion to the sketch of a mountain scene with a boat on a lake at the centre of the poem. In the year before the composition of 'I visit thee', having already read deeply in Byron's works, Shelley met the older poet for the first time on the shores of Lake Geneva. ${ }^{18}$ The two poets took journeys by boat on the lake, and Shelley sketched his surroundings whilst in Switzerland. ${ }^{19}$ It was during this trip that Shelley bought the notebook in which he later composed 'I visit thee', and it is the same Alpine scene-with its depiction of mountain, lake, and boat-that reappears in the pencil and ink sketch at the centre of the lyric. ${ }^{20}$ 'I visit thee' also shows some literary resonances with the Geneva summer: the 'homeless winds' and image of the beating heart recall the sonnet 'Upon the Wandering winds', and these images resemble the failing spirit 'Driven like a homeless cloud' in 'Mont Blanc'. ${ }^{21}$ Bruce Barker-Benfield has suggested that in the 'I visit thee' sketch 'the peaks behind seem more Alp than Cotswold'. ${ }^{22}$ Viewing the drawing alongside the allusion to Byron's poetry, and the similarities to Shelley's poetry of 1816,

\footnotetext{
${ }^{14}$ An allusion noticed by Neth in The Complete Poetry of Percy Bysshe Shelley III, 790.

15 The Complete Poetical Works, III, 114.

16 The Complete Poetry of Percy Bysshe Shelley, III, 276.

17 Bodleian MS. Shelley adds. e. 10, p. 133. Reproduced in The Bodleian Shelley Manuscripts Volume XVII, 144.

18 Shelley's knowledge of Byron's poetry up to 1816 is shown in a letter which he wrote to Hogg while reading the Childe Harold's Pilgrimage III manuscript, see The Letters of Percy Bysshe Shelley I, 493.

19 The most impressive of these sketches is at MS. Shelley adds. c. 4, f. 71 v. Reproduced in The Bodleian Shelley Manuscripts Volume XI, ed. M. Erkelenz (New York: Garland, 1992), p. 154.

${ }^{20}$ For more on the purchase and make-up of this notebook see The Bodleian Shelley Manuscripts Volume XXIII, ed. T. Tokoo and B. C. Barker-Benfield (New York: Routledge, 2002), pp. 33-34.

21 The Complete Poetry of Percy Bysshe Shelley, III, 71, 83.

22 B. Barker-Benfield, Shelley's Guitar (Oxford: Bodleian Library, 1992), 81.
} 
shows the nostalgia for the Geneva summer embedded in these two notebook pages.

Who the narrator is visiting and the location of the 'former home' is unresolved, but the two points established-that there is an allusion to Byron and a memory of the previous summer-augment our understanding of the lyric. The home and addressee of 'I visit thee' need not be a specific place or person, but may be an amalgam of a number of places and feelings. Bishopsgate should be part of this consideration, but so too should the house at 26 Marchmont street which Shelley returned to from Switzerland in September 1816. On his arrival he wrote to Byron of the place where he had lived with Mary Shelley and Claire Clairmont, 'I arrive here - at my antient lodgings; dreadfully vacant and lonely. No companions but the ghosts of old remembrances, all of whom contrive to make some reproach to which there is no reply'. ${ }^{23}$ The idea of home may also include the Villa Diodati, that Shelley revisits through the drawing at the poem's centre; it was this home that Mary Shelley recalled in May 1817 as she read Childe Harold III, noting 'the lake was before us and the mighty Jura. That time is past and this will also pass when I may weep to read these words and again moralize on the flight of time'. 24

'I visit thee' seems to be an imagined situation reflecting on 'the flight of time': the time enjoyed at 'home' in Bishopsgate, the Villa Diodati, and Marchmont Street, can now only be visited through memory, and this is set against a cold present that included the suicides of Fanny Godwin and Harriet Shelley, and the literary stagnation that saw Shelley admit to Byron in January 1817, 'I often talk, and oftener think, of you; and that, though I have not seen you for six months, I still feel the burden of my own insignificance and impotence'. 25 The entwining of literary and personal tensions in this lyric is a sustained feature of Shelley's poetry. In a lyric to Edward and Jane Williams written months before his death the sense of transience achieved by the allusion to Byron in 'I visit thee' returns, when Shelley addresses a figure thought to be Mary,

When I return to my cold home, you ask

Why I am not as I have lately been?26

Here in neat lyric stanzas, which earlier explore the public's indifference towards his poetry, Shelley develops in equally clipped diction the painful transience he expressed in 'I visit thee'. This stable and refined poem is quite different to a fragment, but through a proper exposition of the allusion to Byron and the importance of the Geneva summer it is possible to see 'I visit thee' as a lyric that reveals the burdens of loss and change that define Shelley's mature lyric verse.

\footnotetext{
23 The Letters of Percy Bysshe Shelley, I, 505.

${ }^{24}$ Mary Shelley, The Journals of Mary Shelley, 1814-1844, ed. P. R. Feldman and D. Scott-Kilvert (Oxford: Oxford University Press, 1987), I, 171-172.

25 The Letters of Percy Bysshe Shelley, I, 530.

${ }_{26}$ Percy Bysshe Shelley, 'To-' ('The serpent is shut out from Paradise'), 1l. 25-6, The Major Works, ed. M. O’Neill and Z. Leader (Oxford: Oxford University Press, 2003), 592.
} 